\title{
The Environmental Worldview of Youth in a Secondary School in Kosovo-A Pro NEP Perspective
}

\author{
Pajtim Bytyqi ${ }^{1}$, Ferdije Zhushi Etemi ${ }^{2 *}$, Murtezan Ismaili ${ }^{1}$, Mile Srbinovski ${ }^{1}$, \\ Osman Fetoshi ${ }^{2}$, \& Albona Shala-Abazi ${ }^{3}$ \\ ${ }^{1}$ South East European University, Faculty of Contemporary Sciences and Technologies, Ilindenska 335, \\ Tetovo Macedonia \\ ${ }^{2 *}$ Department of Biology, Faculty of Mathematics and Natural Sciences, University of Prishtina, \\ Mother Teresa 5, Prishtina 10000, Kosovo \\ ${ }^{3}$ Faculty of Agriculture and Veterinary Medicine, University of Prishtina, Mother Teresa 5, \\ Prishtina 10000, Kosovo \\ Corresponding author Ferdije Zhushi Etemi: email: ferdijezhushi2010@gmail.com; \\ phone: +37744249636
}

\begin{abstract}
In this paper we present the results of the investigation of the environmental worldview of the young people from Kosovo, using the New Ecological Paradigm-15-item NEP scale. The scale was administered to 300 students at age 17-19 (upper secondary level) in a secondary school in the city of Malisheva. The Mean Total Pro -NEP score of $63.32 \%$ indicates a pro-ecological orientation of young people from this community with a solid understanding of environmental problems and increased level of responsibility for nature protection.
\end{abstract}

Keywords: environmental worldview, students, NEP scale, Malisheva, Kosovo

\section{Introduction}

The human activities strongly contribute to global pollution of the environment. Among other, human behavior change is necessary for mitigation. From that, the psychological studies of environmental attitudes and worldview are very important. Environmental attitudes are beliefs of people in relation to issues of the environment and nature. Environmental worldview can be defined as "the collective beliefs and values that give people a sense of how the world works, their role in the environment, and right and wrong behavior toward the environment. Environmental worldviews dictate how we interact with nature and our attitude toward how we use the natural resources it contains" (Gillaspy, 2015: 1).

There are many scale to measure environmental attitudes and concern (see: Wiseman and Bogner, 2003; Weigel and Weigel, 1978; Maloney, Ward, and Braucht, 1975. A widely used measure of environmental worldview for the last 35 years is Dunlap and Van Liere's New Environmental Paradigm (NEP, 1978) scale. Previous scales focused on environmental attitudes and concerns about specific problems, such as pollution and misuse of natural resources (see Iozzi, 1981).

The NEP was revised by Dunlap et al. (2000) and became the New Ecological Paradigm Scale. The revised NEP Scale appears to be an improved measuring instrument compared to the original version, as it (1) provides more comprehensive coverage of the key facets of an ecological worldview: the reality of limits to growth, anti-anthropocentrism, the fragility of nature's balance, rejection of exemptionalism, and the possibility of an eco-crisis, (2) avoids the unfortunate lack of balance in the item direction of the original scale (where only four items, all dealing with anthropocentrism, were stated in an anti-NEP direction, and (3) removes the outmoded, sexist terminology in some of the original scale's items (Dunlap et al. 2000: 425, cit. in Srbinovski, 2016).

Students are very important segment of society and from that they are one of the commonly studied population groups in environmental studies. "They will be working in various sectors of society in the near future and performing important works such as managers, teachers, businessmen, 
industrialists and the like. The future quality and stability of life on our planet depends on youngsters developing the worldview necessary for making informed and sensitive decisions about the environment and becoming active participant in the creation of sustainable world" (Erdogan, 2013).

From that few doubt the urgency of environmental education today. Based on the qualitative and quantitative analysis of 36 documents related to environmental education, Srbinovski M. (2004, 2005) defined the term environmental education in the following way:

"Environmental education is a developing process of active learning in which individuals and groups acquire the necessary knowledge, understanding, attitudes and skills for a determined, motivated, responsible, and above all, joint action towards obtaining and maintaining a dynamic balance in the environment". This definition includes the essential components (attitudes, awareness, knowledge, skills and action) of environmental literacy as the ultimate goal of environmental education (Srbinovski, 2005).

Many studies are focused on students' environmental attitudes, concerns, behaviors, worldviews and knowledge: Johnson, Bowker \& Cordell, 2004; Ismaili et al. 2009, Srbinovski, 2003, 2004, 2005a, 2005b, 2006, 2016; Zelezny, Chua, \& Aldrich, 2000; Tuncer, Ertepinar, Tekkaya, Sungur, 2005; Schahn, 1990 etc.

It is an unquestionable fact that there is increasing need to conduct academic and administrative studies in Kosovo. Thus, this article was designed to examine the environmental worldviews of the students from Kosovo.

\section{Methods}

The following hypothesis was put forward: We expect the most students from Kosovo have proecological orientation. Revised New Environmental Paradigm scale or New Ecological Paradigm scale known as the NEP scale developed by Dunlap et al. (2000) was used in this research. The 15-item revised NEP scale (Dunlap et al., 2000: 433) uses a 5-point Likert scale to measure endorsement of an ecological worldview (Table 1). Each item was measured on a scale ranging from 1 to 5: strongly agree (5), agree (4), neither agree or disagree (3), disagree (2), and strongly disagree (1).

The NEP score is calculated as the sum of positive responses for each item: strongly agree plus agree. As the directionality of the anthropocentric items was reversed, the NEP score of these items was adjusted. Mean total pro-NEP\% is average NEP score. Agreement with the eight odd-numbered items indicates pro-NEP orientation, while agreement with the seven even numbered ones indicates pro-DSP orientation. The boundary between a proecological perspective and a human-dominance one is generally held to be a NEP score of 45 (Rideout, et al. 2005, cit. in Van Petegem and A. Blieck, 2006). People scoring below 45 tend to be more in favour of the DSP worldview, whereas those with scores higher than 45 tend to be more in favour of the NEP worldview (Van Petegem and A. Blieck, 2006).

TABLE I. Items in revised NEP Scale (Dunlap et al., 2000)

\begin{tabular}{|l|}
\hline 1. We are approaching the limit of the number of people the earth can support \\
\hline 2. Humans have the right to modify the natural environmental to suit their needs \\
\hline $\begin{array}{l}\text { 3. When humans disturb interfere with nature it often } \\
\text { produces disastrous consequences. }\end{array}$ \\
\hline $\begin{array}{l}\text { 4. Human ingenuity will insure that we do NOT make } \\
\text { the earth unlivable. }\end{array}$ \\
\hline 5. Humans are severely abusing the environment. \\
\hline $\begin{array}{l}\text { 6. The earth has plenty of natural resources if we just } \\
\text { learn how to develop them. }\end{array}$ \\
\hline $\begin{array}{l}\text { 7. Plants and animals have as much right as humans } \\
\text { to exist. }\end{array}$ \\
\hline $\begin{array}{l}\text { 8. The balance of nature is strong enough to cope with } \\
\text { the impacts of modern industrial nations. }\end{array}$ \\
\hline
\end{tabular}




\begin{tabular}{|l|}
\hline $\begin{array}{l}\text { 9. Despite our special abilities humans are still subject } \\
\text { to the laws of nature. }\end{array}$ \\
\hline $\begin{array}{l}\text { 10. The so-called "ecological crisis" facing humankind } \\
\text { has been greatly exaggerated. }\end{array}$ \\
\hline $\begin{array}{l}\text { 11. The earth is like a spaceship with very limited room } \\
\text { and resources. }\end{array}$ \\
\hline 12. Humans were meant to role over the rest of nature. \\
\hline $\begin{array}{l}\text { 13. The balance of nature is very delicate and easily } \\
\text { upset. }\end{array}$ \\
\hline $\begin{array}{l}\text { 14. Humans will eventually learn enough about how } \\
\text { nature works to be able to control it. }\end{array}$ \\
\hline $\begin{array}{l}\text { 15. If things continue on their present course, we will } \\
\text { soon experience a major ecological catastrophe. }\end{array}$ \\
\hline
\end{tabular}

The sample used in the final analysis consisted of 300 students at age 17-19 (upper secondary level) in a secondary school in the city of Malisheva.

\section{Results and Discussions}

The results of the investigation of the environmental worldview of the young people from Kosovo are presented at the Table 2. Mean total pro-NEP\% of the students is about $63 \%$.

TABLE II. Frequency distributions for the NEP scale (N=300).

\begin{tabular}{|c|c|c|c|c|c|c|c|c|}
\hline NEP & \% & a & 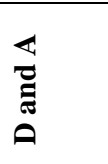 & $<$ & 『ు & 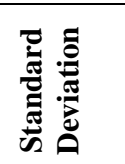 & 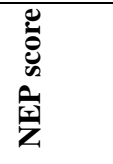 & $0^{2}$ \\
\hline $\begin{array}{l}\text { 1. We are approaching the } \\
\text { limit of the number of people the } \\
\text { earth can support. }\end{array}$ & $\begin{array}{l}18 \\
6 \%\end{array}$ & $\begin{array}{l}27 \\
9 \%\end{array}$ & $\begin{array}{l}96 \\
32 \%\end{array}$ & $\begin{array}{c}95 \\
31.6 \%\end{array}$ & $\begin{array}{c}64 \\
21.3 \%\end{array}$ & 32.83 & 3.533 & 70.6 \\
\hline $\begin{array}{l}\text { 2. Humans have the right } \\
\text { to modify the natural } \\
\text { nvironmental to suit their needs }\end{array}$ & $\begin{array}{l}27 \\
9 \%\end{array}$ & $\begin{array}{c}32 \\
10.6 \%\end{array}$ & $\begin{array}{c}61 \\
20.3 \%\end{array}$ & $\begin{array}{c}110 \\
36.6 \%\end{array}$ & $\begin{array}{c}70 \\
23.3 \%\end{array}$ & 29.91 & 2.23 & 44.6 \\
\hline $\begin{array}{l}\text { 3. When humans disturb } \\
\text { interfere with nature it often } \\
\text { produces } \\
\text { consequences. }\end{array}$ & $\begin{array}{c}1 \\
7 \\
2.3 \%\end{array}$ & $\begin{array}{c}2 \\
12 \\
4 \%\end{array}$ & $\begin{array}{c}3 \\
24 \\
8 \%\end{array}$ & $\begin{array}{c}4 \\
105 \\
35 \%\end{array}$ & $\begin{array}{c}5 \\
152 \\
50.6 \%\end{array}$ & 58.13 & 4.27 & 85.4 \\
\hline $\begin{array}{l}\text { 4. Human ingenuity will } \\
\text { insure that we do NOT make } \\
\text { the earth unlivable. }\end{array}$ & $\begin{array}{c}1 \\
13 \\
4.33 \%\end{array}$ & $\begin{array}{c}2 \\
27 \\
9 \%\end{array}$ & $\begin{array}{c}3 \\
75 \\
25 \%\end{array}$ & $\begin{array}{c}4 \\
98 \\
32.6 \%\end{array}$ & $\begin{array}{c}5 \\
87 \\
29 \%\end{array}$ & 33.75 & 2.27 & 45.4 \\
\hline $\begin{array}{l}\text { 5. Humans are severely } \\
\text { abusing the environment. }\end{array}$ & \begin{tabular}{c|c|}
1 \\
14 \\
$4.66 \%$ \\
\end{tabular} & $\begin{array}{c}2 \\
20 \\
6.66 \%\end{array}$ & $\begin{array}{c}3 \\
27 \\
9 \%\end{array}$ & $\begin{array}{c}4 \\
119 \\
39.66 \%\end{array}$ & $\begin{array}{c}5 \\
120 \\
40 \% \\
\end{array}$ & 48.75 & 4.036 & 80.8 \\
\hline $\begin{array}{l}\text { 6. The earth has plenty of } \\
\text { natural resources if we just } \\
\text { learn how to develop them. }\end{array}$ & $\begin{array}{c}1 \\
1 \\
0.3 \%\end{array}$ & $\begin{array}{c}2 \\
7 \\
2.33 \%\end{array}$ & $\begin{array}{c}3 \\
15 \\
5 \%\end{array}$ & $\begin{array}{c}4 \\
80 \\
26.6 \%\end{array}$ & $\begin{array}{c}5 \\
197 \\
65.6 \%\end{array}$ & 74.14 & 1.436 & 28.8 \\
\hline $\begin{array}{l}\text { 7. Plants and animals have as } \\
\text { much right as humans } \\
\text { to exist. }\end{array}$ & $\begin{array}{c}1 \\
3 \\
1 \% \\
\end{array}$ & $\begin{array}{c}2 \\
18 \\
6 \% \\
\end{array}$ & $\begin{array}{c}3 \\
48 \\
16 \% \\
\end{array}$ & $\begin{array}{c}4 \\
111 \\
37 \% \\
\end{array}$ & $\begin{array}{c}5 \\
120 \\
40 \% \\
\end{array}$ & 47.66 & 4.09 & 81.8 \\
\hline $\begin{array}{l}\text { 8. The balance of nature is } \\
\text { strong enough to cope with } \\
\text { the impacts of modern industrial } \\
\text { nations. }\end{array}$ & $\begin{array}{c}1 \\
41 \\
13.6\end{array}$ & $\begin{array}{c}2 \\
68 \\
22.66 \%\end{array}$ & $\begin{array}{c}3 \\
99 \\
33 \%\end{array}$ & $\begin{array}{c}4 \\
71 \\
23.66 \%\end{array}$ & $\begin{array}{c}5 \\
21 \\
7 \%\end{array}$ & 26.78 & 3.12 & 62.4 \\
\hline $\begin{array}{c}9 . \quad \text { Despite our special } \\
\text { abilities humans are still subject }\end{array}$ & $\begin{array}{l}1 \\
7\end{array}$ & $\begin{array}{c}2 \\
18 \\
\end{array}$ & $\begin{array}{c}3 \\
47 \\
\end{array}$ & $\begin{array}{c}4 \\
127 \\
\end{array}$ & $\begin{array}{c}5 \\
101 \\
\end{array}$ & 46.71 & 3.99 & 79.8 \\
\hline
\end{tabular}




\begin{tabular}{|c|c|c|c|c|c|c|c|c|}
\hline to the laws of nature. & $2.33 \%$ & $6 \%$ & $15.66 \%$ & $42.23 \%$ & $33.66 \%$ & & & \\
\hline $\begin{array}{l}\text { 10. The so-called "ecological } \\
\text { crisis" facing humankind } \\
\text { has been greatly exaggerated. }\end{array}$ & $\begin{array}{c}1 \\
22 \\
7.33 \%\end{array}$ & $\begin{array}{c}2 \\
40 \\
13.33 \%\end{array}$ & $\begin{array}{c}3 \\
123 \\
41 \% \\
\end{array}$ & $\begin{array}{c}4 \\
71 \\
23.66 \%\end{array}$ & $\begin{array}{c}5 \\
44 \\
14.66 \%\end{array}$ & 35.18 & 2.75 & 55.0 \\
\hline $\begin{array}{l}\text { 11. The earth is like a } \\
\text { spaceship with very limited room } \\
\text { and resources. }\end{array}$ & $\begin{array}{c}1 \\
26 \\
8.66 \% \\
\end{array}$ & $\begin{array}{c}2 \\
38 \\
12.66 \% \\
\end{array}$ & $\begin{array}{r}3 \\
55 \\
18.33 \% \\
\end{array}$ & $\begin{array}{c}4 \\
112 \\
37.33 \%\end{array}$ & $\begin{array}{c}5 \\
69 \\
23 \% \\
\end{array}$ & 29.83 & 3.53 & 70.6 \\
\hline $\begin{array}{l}\text { 12. Humans were meant to } \\
\text { role over the rest of nature. }\end{array}$ & $\begin{array}{c}1 \\
44 \\
14.66 \% \\
\end{array}$ & $\begin{array}{c}2 \\
64 \\
21.33 \%\end{array}$ & $\begin{array}{c}3 \\
81 \\
27 \% \\
\end{array}$ & $\begin{array}{c}4 \\
87 \\
29 \% \\
\end{array}$ & $\begin{array}{c}5 \\
24 \\
8 \% \\
\end{array}$ & 23.40 & 3.05 & 61.0 \\
\hline $\begin{array}{l}\text { 13. The balance of nature is } \\
\text { very delicate and easily } \\
\text { upset. }\end{array}$ & $\begin{array}{c}1 \\
81 \\
27 \% \\
\end{array}$ & $\begin{array}{c}2 \\
46 \\
15.33 \% \\
\end{array}$ & $\begin{array}{r}3 \\
55 \\
18.33 \% \\
\end{array}$ & $\begin{array}{c}4 \\
76 \\
25.33 \% \\
\end{array}$ & $\begin{array}{c}5 \\
42 \\
14 \% \\
\end{array}$ & 15.76 & 2.84 & 56.8 \\
\hline $\begin{array}{l}\text { 14. Humans will eventually } \\
\text { learn enough about how } \\
\text { nature works to be able to control } \\
\text { it. }\end{array}$ & $\begin{array}{c}1 \\
14 \\
4.66 \%\end{array}$ & $\begin{array}{c}2 \\
17 \\
5.66 \%\end{array}$ & $\begin{array}{c}3 \\
79 \\
26.33 \%\end{array}$ & $\begin{array}{c}4 \\
114 \\
38 \%\end{array}$ & $\begin{array}{c}5 \\
76 \\
25.33 \%\end{array}$ & 38.72 & 2.26 & 45.2 \\
\hline $\begin{array}{l}15 . \text { If things continue on } \\
\text { their present course, we will } \\
\text { soon experience a major } \\
\text { ecological catastrophe. }\end{array}$ & $\begin{array}{c}1 \\
12 \\
4 \%\end{array}$ & $\begin{array}{c}2 \\
21 \\
7 \%\end{array}$ & $\begin{array}{c}3 \\
43 \\
14.33 \%\end{array}$ & $\begin{array}{c}4 \\
79 \\
26.33 \%\end{array}$ & $\begin{array}{c}5 \\
145 \\
48.33 \%\end{array}$ & 48.37 & 4.08 & 81.6 \\
\hline TOTAL & & & & & & & & 63.32 \\
\hline
\end{tabular}

*SD- strongly disagree, D- disagree, A- agree, SA- strongly agree

Range on the responses of the students on the pro-environmental items are from 56.80 ("The balance of nature is very delicate and easily upset") to $85.40 \%$ ("When humans disturb interfere with nature it often produces disastrous consequences". Mean total on these items of the students is $75.96 \%$. On the other hand, range on the responses of the students on the pro-DSP\% items are from 28.80 ("The earth has plenty of natural resources if we just learn how to develop them") to $62.40 \%$ ("The balance of nature is strong enough to cope with the impacts of modern industrial nations". Mean total on these items of the students is $48.91 \%$.

The Mean Total Pro -NEP score indicates a pro-ecological orientation of young people from this community with a solid understanding of environmental problems and increased level of responsibility for nature protection.

Very similar results we find in a part of the research by Van Petegem and Blieck A. (2006). In their research they investigate the worldviews of young people in Belgium and Zimbabwe, using Manoli et al.'s revised NEP scale for children. The Belgian children are more in favour of the NEP worldview (mean NEP score of 63.18) than the children in Zimbabwe (mean NEP score of 51.44) indicating that the Belgian children display pro-ecological conceptions more than the children in Zimbabwe.

A study by Srbinovski M. (2016) was focused on the impact of gender on environmental worldview in a sample of Macedonian students. Empirical findings suggest that no firm and clear conclusions can be drawn about the effects of gender on (NEP) environmental concern. Most studies find that women score higher than men on environmental concern (Zelezny et al., 2000; Tuncer et al., 2005: Schahn \& Holzer, 1990).

Many factors create a pro-ecological orientation of young people. From that, more researches are needed in this field.

It is important to note the limitations of this investigation. First, the random sample is relatively small. Second, the sample consisted only of students from secondary schools. Future researchers will use large, representative "mixed" samples. Despite these limitations, these results provide an intriguing insight into student's worldviews from Kosovo. With other words, the present study is only a small part of ongoing studies of environmental worldview of the people in Kosovo. 


\section{References}

[1] Dunlap, R. E. \& Van Liere, K. D, "The New Environmental Paradigm: A Proposed Measuring Instrument and Preliminary Results" The Journal of Environmental Education. 9 (4), 10-19. 1978 DOI: 10.1080/00958964.1978.10801875.

[2] Dunlap, R. E., Van Liere, K. D., Mertig, A. G. \& Jones, R. E, “ Measuring the endorsement of the New Ecological Paradigm: a revised NEP scale” Journal of Social Issues.56 (3), 425-442. 2000 Retrieved August 3, 2016. from www: http://academic.evergreen. edu/s/smitht/NEP.pdf.

[3] Erdogan, N, "Environmental wordviews in higher education: a case study of Turkish college students" ProcediaSocial and Behavioral Sciences 106: 1086-1095.2013

[4] Gillaspy, R, "Environmental Worldviews: Western \& Deep Ecology" 2015 Retrieved Mars 3, 2017 from www: http://study.com/academy/lesson/ environmental- worldviews-western-deep-ecology.

[5] Iozzi, L. A, "Research in environmental education 1971-1980". ED 214 762, 1981

(Columbus, OH,ERIC Clearinghouse for Science, Mathematics and Environmental Education).

[6] Ismaili, M., A. Abazi \& Srbinovski, M, "Students' level of environmental education in Macedonian high schools" SEEU (South East European University) Review 5 (2), 125-135. 2009

[7] Johnson, C. Y., Bowker, J. M. \& Cordell, H.K, "Ethnic variation in environmental belief and behavior. An examination of the New Ecological Paradigm in a social psychological context" Environment and Behavior, 36 (2), 157-186. 2004

[8] Maloney, M. P., Ward, M. P. \& Braucht, G. N, “A revised scale for the measurement of ecological attitudes and knowledge" American psychologist.30 (7), 787-790. 1975, DOI: 10.1037/h0084394.

[9] Schahn, J. \& Holzer, E, "Studies of individual environmental concern: The role of knowledge, gender, and background variables" Environment and Behavior. 22, 767-786. 1990. DOI: 10.1177/0013916590226003.

[10] Srbinovski, M, "Methodological problems in the environmental education," Proceedings. . 2003

[11] Srbinovski, M, "Some aspects of the students' environmental education in the Republic of Macedonia" Natura Montenegrina 3, 257-268. 2004

[12] Srbinovski, M, "Environmental Education” Prosvetno Delo, Skopje. 2005a

[13] Srbinovski, M, "What is environmental education" Prosvetno Delo, 4: 79-97, 5: 65-77. . 2005b

[14] Srbinovski, M, "Gender Differences in Environmentalism: A Case Study of Macedonian Students" Teaching Innovations, 4:101-114. 2016

[15] Tuncer, G., Ertepinar, H., Tekkaya, C. \& Sungur, S, "Environmental Attitudes of Young People in Turkey: Effects of School Type and Gender" Environmental Education Research. 11 (2), 215-233. 2005, DOI: 10.1080/1350462042000338379.

[16] Van Petegem, P. \& Blieck, A, "The environmental worldview of children: a cross-cultural perspective" Environmental Education Research, Vol. 12, No. 5, pp. 625-635. 2006

[17] Weigel, R. \& Weigel, J, "Environmental concern: the development of a measure” Environment and Behavior.10 (1), 3-15. 1978, DOI: 10.1177/0013916578101001.

[18] Wiseman, M. \& Bogner, F. X, "A higher-order model of ecological values and its relationship to personality" Personality and Individual Differences. 34 (5), 783-794. 2003, DOI: 10.1016/S0191-8869(02)00071-5.

[19] Zelezny, L. C., Chua, P. P. \& Aldrich, C, "New Ways of Thinking about Environmentalism: Elaborating on gender differences in environmentalism" Journal of Social Issues. 56 (3), 443-457, 2000, DOI: 10.1111/0022-4537.00177. 